Journal of Sustainable Development of Transport and Logistics

journal home page: https://jsdtl.sciview.net

Onwuegbuchunam, D. E., Aponjolosun, M. O., Oludare, A. A., \& Onyekachi. O. C. (2020).

Assessment of Cabotage Act implementation and its effect on Nigerian seafarers. Journal of

Sustainable Development of Transport and Logistics, 5(1), 124-132.

doi:10.14254/jsdtl.2020.5-1.12.

\title{
Assessment of Cabotage Act implementation and its effect on Nigerian seafarers
}

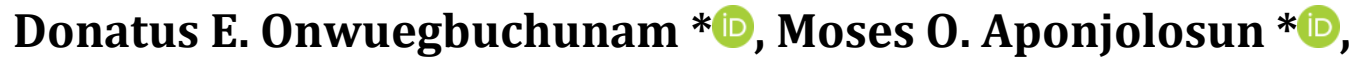 \\ Ayotunde A. Oludare **, Okafor C. Onyekachi * \\ ${ }^{*}$ Department of Maritime Management Technology, Federal University of Technology Owerri, \\ P.M.B 1526, Nigeria \\ ${ }^{* *}$ Nautical Science Department, Federal College of Fisheries and Marine Technology, \\ P.M.B 80063, Nigeria
}

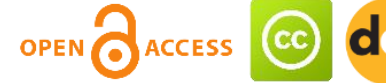

Article history:

Received: March 12, 2020

1st Revision: March 29, 2020

Accepted: April 28, 2020

\section{DOI:}

10.14254/jsdtl.2020.5-1.12

\begin{abstract}
This paper is based on a study that was carried out to assess the implementation of cabotage act in Nigeria from the perspectives of the seafarers and shipowners who are considered as the major stakeholders in maritime sector and are directly affected by this act. The objectives of this study were to evaluate cabotage operations and to ascertain the effect of cabotage act implementation on Nigerian seafarers onboard cabotage vessels. Primary data was used through a design of questionnaire and interview. Fifty (54) copies of questionnaires were retrieved out of 60 copies that were administered. The method of data analysis was descriptive using statistical mean and percentages with the aid of Statistical Package for Social Sciences (SPSS) version 23. The data collected were measured in 5-point Likert scale with a hypothesized mean of 3.00. The findings of the study revealed that despite some successes recorded in the aspect of increase in the number of cabotage vessels operating on Nigeria waters and increase in the number of Nigerian seafarers employed onboard these cabotage vessels, there are still some challenges in respect to the implementation of this act such as, low capacity of Nigerian ship building industry to meet the demand of cabotage trade market, inability of shipowners to access fund to enhance their operations, lack of adequate attention to the condition of service and welfare of Nigerian seafarers onboard cabotage vessels. This study recommends investment in Nigerian shipbuilding industry in order to meet the demand of cabotage trade and also seeks enforcement of the ratified Maritime Labour Convention by Nigeria Maritime Administration and Safety Agency (NIMASA) in order to ensure better working and living conditions for Nigeria Seafarers.
\end{abstract}

Keywords: Cabotage Act, Nigerian seafarers, ship owners, implementation, welfare

Corresponding author: Moses O. Aponjolosun

E-mail: aponmoses@yahoo.com

This open access article is distributed under a Creative Commons Attribution (CC-BY) 4.0 license. 


\section{Introduction}

Cabotage Act (2003) was enacted in order to reduce or eliminate the dominance of foreign vessels in Nigeria waters and spur the growth of indigenous shipping companies engaging in coastal trade in order to contribute to the growth and development of Nigeria economy. Nwekeaku and Atteh (2016) were of the opinion that cabotage act was introduced to stimulate, empower and reposition the indigenous shipping lines for active participation in the Sub-Saharan shipping tractions.

Oluremi (n.d) was of the view that the approach of protecting domestic shipping companies by prohibiting foreign ships from participating in domestic or coastal shipping is one which is recognized all over the world as that based upon the realization that the protection of nation's maritime industry is an avenue for economic advancement and availability of defence/security in situation of national emergencies and crisis. However, cabotage acts which requires that vessels trading within the country's coastal waters should be built domestically, owned and manned by nationals of the country was enacted in 2003 in Nigeria.

Nigeria aspires to be among the top 20 largest economies by the year 2020 according to the economic policy vision of 2020 and successful implementation of cabotage law in Nigeria is critical to the success or otherwise of the plan because of the important role shipping plays in the movement of goods and services around the country and the revenues collected as tax from companies in the sector (Foraminifara Market Research, 2016). Nigeria Maritime Administration and Safety Agency (NIMASA) stated that the need for the enactment of Coastal and Inland Shipping (Cabotage) Act, 2003 in Nigeria was necessary in order to change the face of maritime business within the coast (www.nimasa.gov.ng/servises/cabotage-service). The coastal and inland shipping act 2003 identified four pillars of cabotage which are vital to its implementation. These four pillars give exclusive control and operations of domestic shipping to Nigerians. However, these four pillars stated that; (i) vessels must be built in Nigeria (ii) vessel(s) must be registered in Nigeria (iii) vessels must be wholly manned by Nigerians (iv) vessels must be wholly owned by Nigerians.

It must be noted that the beneficial expectations from the implementation of cabotage act include; boost in inland water transport operation thereby help in reducing over-reliance on road transportation in Nigeria, creation of employment opportunities, development of indigenous shipping companies, inland water deport and transfer of technology in the arears of repairs and building of vessels in Nigeria.

\section{Research objectives}

i. To evaluate cabotage vessels operations with the implementation of Cabotage Act

ii. To determine the effect of cabotage act implementation on Nigerian seafarers onboard cabotage vessels

\section{Problem statement}

It is over a decade and a half that cabotage act was implemented in the Nigeria. There has been numerous studies and scholarly written articles concerning cabotage implementation in Nigeria. Njar and Okon (2018) wrote on the impacts of cabotage law implementation on Nigeria's indigenous shipping industry: a study of the Onne sea port, rivers state, Nigeria. Ajiye (2013) analysed the prospects and challenges of Nigerian cabotage. Atteh and Nwekeaku (2016) investigated factors militating against the utilization of the Nigerian Cabotage Act 2003 to revamping the ailing shipping industry. However, issues relating to the welfare and remuneration of Nigerian seafarers working on cabotage vessels with the implementation of the act have not received the needed attention. Hence, assessing the effect of Cabotage Act implementation on the welfare of Nigerian seafarers is the premise upon which this study is based.

\section{Literature review}

Nigeria is blessed with a large resource base of waterways spanning 10,000 kilometers; about 3,800 kilometers is navigable seasonally. Twenty-eight of the nation's 36 States can be accessed 
through water. The Rivers Niger and Benue constitute the major channels for inland navigation which include but not limited to the Cross River, Port Novo-Badagry-Lagos waterways, Lekki and Lagos Lagoons, Ogun-Ondo waterways, Benin River, Escravos channel, Nun River, Imo River, Orashi River, Ethiope River Ugwuta Lake, Lake Chad and the numerous creeks in the Niger delta (https://niwa.gov.ng/waterways/).

It is of a fact that the importance of maritime activities locally and internationally cannot be over emphasized as the global trade is largely dependent on water transportation. Effective and efficient transportation with good legislations or policies in place and with proper implementation will definitely contribute immensely to the economic growth and development of a nation. It must be noted that cabotage act 2003 was implemented in Nigeria to serve as a tool that will improve the coastal trade and contribute to the economic development.

Cabotage is said to have originated from French and Spanish. According to Merriam- Webster dictionary, the French came up with the word "Caboter" which means the act of sailing along a coast (https://www.merriam- webster.com/dictionary/cabotage). In the $16^{\text {th }}$ century, the French legally limited the lucrative coastal trade in French ports. Henry (1968) explained that cabotage is a nautical term from Spanish, denoting strictly navigation from cape to cape along the coast without going out into the open sea. From the explanations above, it can be concluded that Cabotage simply means transportation by water within the coastal or territorial waters of a particular country.

In addition, Coastal and Inland Shipping (cabotage) Act 2003 has a detailed explanation for the term "cabotage", which is stated as follows;

a) the carriage of goods by vessel, or by vessel and any other mode of transport, from one place in Nigeria or above Nigeria waters to any other place in Nigeria or above Nigeria waters, either directly or via a place outside Nigeria and includes the carriage of goods in relation to the exploration, exploitation or transportation of the mineral or non-living natural resources of Nigeria whether in or under Nigerian waters;

b) the carriage of passengers by vessel from any place in Nigeria situated on a lake of river to the same place, or to any other place in Nigeria, either directly or via a place outside Nigeria to the same place without any call at any port outside Nigeria or to any other place in Nigeria, other than as an in-transit or emergency call, either directly or via a place outside Nigeria;

c) the carriage of passengers by vessel from any place in Nigeria to any place above or under Nigerian waters to any place in Nigeria, or from any place above Nigerian waters to the same place or to any other place above or under Nigerian waters where the carriage of the passengers is in relation to the exploration, exploitation or transportation of the mineral or non-living natural resources in or under Nigerian waters; and

d) the engaging, by vessel, in any other marine transportation activity of a commercial nature in Nigerian waters and, the carriage of any goods or substances whether or not of commercial value within the waters of Nigeria.

Furthermore, in respect to section 22(5) of the Cabotage Act, Cabotage vessels can be defined as vessels such as passenger vessels, crew boats, bunkering vessels, fishing trawlers, barges, offshore service vessels, floating petroleum storage, dredgers, tankers, carriers and any other craft or vessel used for carriage on, through or underwater of person, property or any substance whatsoever.

\section{Types of maritime cabotage policies}

There are two forms of cabotage polices which defined the extent of participation of foreign vessels in the country's coastal waters. These policies are strict cabotage policy and relaxed or liberalised policy. The application of these policies varies from countries to countries and is largely dependent on their objectives, national interests and local situations (Olowookere, 2011). These policies are explained as follows;

1. Strict Cabotage Policy: Strict cabotage policy which be said to be protectionist policy means economic policy which restrict coastal trade within a particular country or between countries through the implementation of tariffs, quotas and non-tariff barriers. Casaca and Lyrids (2018) stated that strict cabotage policies imply that:

- The controlling shares of shipping companies must be, at least 51 per cent, in hands of nationals 
- The vessel ownership must be, at least 51 per cent, in hands of nationals so that's vessels bought by those companies belong to a national fleet.

- Shipbuilding and repairs are performed by national companies

- Vessels are obliged to be registered under the national flag and crewed in total or partially by nationals

Also, the four pillars of Nigerian cabotage Act which restrict the coastal trade to ships built, owned, manned and operated by Nigerians as contained in Part II Section 3-7 of the Act is an indication of a strict cabotage policy. Casaca and Lyrids (2018) stated that the problem with Nigeria is that the act enforcing the regime is far from being implemented and so market liberation is still in force in force. In addition, the waiver clause which gives the foreign vessels right to operate domestically in our waters has liberalized the strictness of the Act and has made the implementation of cabotage Act in Nigeria difficult. Countries that adopt strict cabotage policy are United States, Japan and Peru.

2. Relaxed Cabotage Policy: Olowookere (2011) (citing Igbokwe, 2006) stated that cabotage law can be said to be relaxed or liberalised if the elements of restrictions stated under strict cabotage policy are not required to be complied with or are strictly enforced and there are some measures of foreign participation in the ownership or building of the vessels used and in the nationality of operators involved (e.g., the crew) or of foreign - flagged vessels' involvement in a state's coastal shipping. Casaca and Lyridis (2018) were of the opinion that the reasons that lead countries to adopt liberalised market policies in detriment of protectionist ones through free trade policies enforced by international treaties and organizations are many and generally, they fall within the scope of economic legal, social strategic and cultural perspectives. Some of the envisaged benefits of adopting liberalized cabotage policies include encouragement of competition which promote or boost the economic activities domestically. Also, Casaca and Lyridis (2018) stated that from the perspective of vessel's economy, they can contribute to find new ways of operation that contribute to lower freight rates as ship operators will be able to outsource their supplies worldwide in which at the end, only the most effective efficient companies will survive. Examples of countries that practiced relaxed or liberalised cabotage policy are China, Korea, Brazil, India and so on.

\section{Recent developments in the Implementation cabotage}

It is a well-known fact that implementation of cabotage policy in Nigeria is saddled with a lot of challenges, however, some achievements have been recorded so far in this regard in the recent time with the new cabotage compliance strategy.

In 2017, NIMASA introduced the new Cabotage Compliance Strategy (CCS) for a successful Coastal and Inland trade regime thereby halting consideration of applications for grant of waivers on manning for prescribed category of Officers on vessels engaged on cabotage trade. Alayaki (2019) reported that in early 2008 the international oil companies operating in Nigeria were specifically instructed that any vessel working for them with a foreigner onboard there should be a succession plan for a Nigerian to take over under the guidance and training of the experienced foreigner. This instruction was given to strategically solve the waiver problem in respect to manning requirements under the cabotage act. However, this led to a rapid increase in the numbers of Nigerians on board cabotage vessels. Also, according to Nigeria's Maritime Industry Forecast (2019) Nigerian flagged vessels has enjoyed significant growth from 262 vessels with a total tonnage of slightly over 232,000 metric tons in 2015, to almost double in 2016 at 370 vessels with a total tonnage of almost 420,000 metric tons and in 2017,307 vessels were registered with a total tonnage of 415,638.

\section{Methodology}

In this study primary data was used through the design of a structured questionnaire and interview. The questionnaire was designed on 5 points Likert rating to measure and analyse the responses of the respondents. A total of 60 questionnaires were administered to Nigerian seafarers and shipowners/operators through a simple random technique. Out of these questionnaires 54 which 
represent $90 \%$ were retrieved. This study carried out a robust evaluation of the response of indigenous seafarers and shipowners/operators in respect to the effect of cabotage act implementation in Nigeria.

\section{Data analysis and presentation}

Data was collected by use of structured questionnaire. The researcher used descriptive statistics to analyse data. This included frequency distribution tables, percentages, mean, and standard deviation. SPSS version 23 software was used to analyse the data.

\subsection{Demographic characteristics of the respondents}

\subsubsection{Gender of the respondents}

Majority of the respondents were male with $85 \%$ while $15 \%$ were females as shown in Table 1 below. This is an indication that Seafaring profession is dominated by males.

\begin{tabular}{lcc} 
Table 1: Gender of the respondents & & \\
Gender & Frequency & Percent \\
\hline Male & 46 & 85 \\
Female & 8 & 15 \\
Total & 54 & 100 \\
\hline
\end{tabular}

\subsubsection{Educational qualification}

In respect to the level of education of respondents as shown in table 2, this study found out that $19 \%$ of the respondents were secondary school graduates while $44 \%$ of the respondents were National diploma/Diploma graduates. $20 \%$ and $6 \%$ of the respondents were found to possess Higher National Diploma (HND) /BSc and MSc respectively. 11\% of the respondents belong to the category of respondents that possess other qualification. This partly explains that the respondents were adequately knowledgeable and were capable of giving information with high degree of relevance.

\begin{tabular}{lcc} 
Table 2: Educational qualification of the respondents & Percent \\
\hline Educational Qualification & Frequency & 19 \\
\hline SSCE/O'Level & 10 & 44 \\
ND/Diploma & 24 & 20 \\
HND/BSc & 11 & 6 \\
MSc & 3 & 11 \\
Others & 6 & 100 \\
Total & 54 & \\
\hline
\end{tabular}

\subsubsection{Work experience of the respondents}

Table 4 depicts the years of work experience of the respondents in order to ascertain their level of understanding and relevance of their contribution to the study. $9 \%$ respondents were under the category of people with 0-5 years of work experience, 33\% respondents were under the category of 6 10 years work experience, $24 \%$ respondents were under the category of 11-15 years of work experience, $19 \%$ were under $16-20$ years while $15 \%$ respondents were under the category of 21 and above years of work experience.

\begin{tabular}{lcc} 
Table 4: Work Experience & Frequency & Percent \\
Work Experience & 5 & 9 \\
\hline $0-5$ & 18 & 33 \\
$6-10$ & 13 & 24 \\
$11-15$ & 10 & 19 \\
$16-20$ & 8 & 15 \\
21 and above & 54 & 100 \\
Total & & \\
\hline
\end{tabular}




\subsubsection{Department and specialization}

Table 5 shows the positions of the respondents and their area of specialization. $11 \%$ of the respondents were ship owners and managers. $6 \%$ of the respondents were captains. Chief mates and third mates which represents the deck officers were found to be $7 \%$ and $9 \%$ respectively while $17 \%$ and $6 \%$ of the respondents who were Able seamen and Ordinary Seamen respectively represent the ratings (unlicensed officers) in the deck department onboard. 7\%, 6\%, and $7 \%$ of the respondents which represent the Chief engineers, second engineers and fourth engineers respectively were licensed officers in the engine room department while $11 \%$ who were motormen represent the ratings (unlicensed officers) in the engine room. $6 \%$ of the respondents were electro-technical officers while $7 \%$ were Maritime Security Liaison Officers on board.

\begin{tabular}{llcc} 
Table 5: Area of specialization of the respondents & & \\
Department/specialization & Positions & Frequency & Percent \\
\hline Ship management & Owner/operator & 6 & 11 \\
Deck & Captain & 3 & 6 \\
Deck & Chief mate/Officer & 4 & 7 \\
Deck & Third mate /Officer & 5 & 9 \\
Deck & Able seaman & 9 & 17 \\
Deck & Ordinary Seaman & 3 & 6 \\
Engine & Chief engineer & 4 & 7 \\
Engine & Second engineer & 3 & 6 \\
Engine & Forth engineer & 4 & 7 \\
Engine & Motorman & 6 & 11 \\
Electrical & Electro-technical officer & 3 & 6 \\
Security & Maritime Security Liaison officer & 4 & 7 \\
Total & & 54 & 100 \\
\hline
\end{tabular}

\subsection{Data analysis in relation to the effect of cabotage act implementation on Nigerian seafarers}

The respondents were asked to rate their extent of agreement to the statement posed to them in respect to the effect of cabotage act implementation on the Nigerian seafarers and shipowners on a five-point Likert scale. The range was strongly agree (5) to strongly disagree (1). The scores of strongly disagree and disagree were taken to represent a component that had small extent (S.E) of agreement which was equivalent to a mean score of 0 to 2.4 on a continuous Likert scale; $(0 \leq \mathrm{S}$. E $\leq$ 2.4). Scores of neutral were taken to represent a component that had a moderate extent (M.E) of agreement which was equivalent to a mean score of 2.5 to 3.4 on the continuous Likert scale: $(2$. $5 \leq \mathrm{M} . \mathrm{E} \leq 3.4$ ). The scores for both agree and strongly agree represented a variable with large extent (L.E) of agreement which was equivalent to a mean score of 3.5 to 5 on a continuous Likert scale; (3.5 L.E $\leq 5.0)$.

\subsubsection{Evaluation of cabotage vessels operations with the implementation of cabotage act}

Table 6: Responses in respect to cabotage vessels operations in Nigeria

\begin{tabular}{|c|c|c|c|}
\hline Constructs & $\mathbf{N}$ & Mean & Std. Deviation \\
\hline $\begin{array}{l}\text { Implementation of cabotage act has contributed to the growth of indigenous } \\
\text { shipping companies }\end{array}$ & 54 & 3.50 & 1.411 \\
\hline Foreign vessels are still dominating Nigerian waters & 54 & 3.94 & 1.123 \\
\hline Non availability of fund hinders growth of cabotage vessels operation in Nigeria & 54 & 3.70 & 1.223 \\
\hline The cabotage vessel financing fund is accessible to shipowners & 54 & 1.59 & .765 \\
\hline A stricter cabotage policy should be adopted & 54 & 4.00 & 1.046 \\
\hline $\begin{array}{l}\text { The current ship building industry in Nigeria does not have the capacity to } \\
\text { satisfy the cabotage trade market }\end{array}$ & 54 & 4.04 & .951 \\
\hline Indigenous ship owners are fully engaged in the cabotage trade & 54 & 2.07 & 1.358 \\
\hline Valid N (listwise) & 54 & & \\
\hline
\end{tabular}


Table 6 shows the responses of the respondents in respect to cabotage vessels operations in Nigeria. The calculated mean of 3.50 shows that implementation of cabotage act has contributed to the growth of indigenous shipping companies. This result supports the report of Nigeria Maritime Industry Forecast (2019) that Nigerian flagged vessels has enjoyed significant growth. Other factors that were rated by the respondents as having the greatest impact included: Domination of Nigerian waters by foreign vessels (3.94), Non availability of fund which hinders growth of cabotage vessels operation in Nigeria (3.70), the current ship building industry in Nigeria which does not have the capacity to satisfy the cabotage trade market (4.04) and the calculated mean in respect to adoption of stricter cabotage policy was 4.00 . The calculated mean of 2.07 reveals that the extent of engagement of indigenous shipowners' participation in cabotage trade is to a small extent. Also calculated mean of 1.59 shows that cabotage vessel financing fund is not accessible to ship owners.

\subsubsection{Effect of Cabotage Act implementation on Nigerian seafarers}

\begin{tabular}{|c|c|c|c|}
\hline Constructs & $\mathbf{N}$ & Mean & Std. Deviation \\
\hline $\begin{array}{l}\text { Condition of service for Nigerian seafarers is very poor compared with that of } \\
\text { foreign counterparts }\end{array}$ & 54 & 4.13 & 1.182 \\
\hline Seafarers manning cabotage vessels are well trained and skilled. & 54 & 2.98 & 1.310 \\
\hline $\begin{array}{l}\text { There is increase in the number of Nigerian seafarers employed with the } \\
\text { implementation of cabotage policy. }\end{array}$ & 54 & 4.15 & 1.323 \\
\hline Nigerian seafarers are among the lowest paid in the world & 54 & 3.96 & 1.081 \\
\hline A general standard minimum wage should be set for indigenous seafarers. & 54 & 4.11 & 1.355 \\
\hline Valid N (listwise) & 54 & & \\
\hline
\end{tabular}

As shown in Table 7, the study found that there is significant increase (mean: 4.15) in the number of Nigerians seafarers employed with the implementation of cabotage act in Nigeria. This result corroborates with the Alayaki (2019) in respect to increase in the number of Nigerian seafarers onboard which is made possible as result of compliance to manning requirement under cabotage act as mandated by NIMASA. However, the condition of service for Nigerian seafarers compared to the foreign counterparts is poor (4.13) and Nigerian seafarers are viewed to be among the lowest paid in the world (3.96). Interview conducted by the researchers in respect to condition of service revealed that they are not only owe salaries/wages but also not well remunerated. The calculated mean of 2.96 reveals a moderate extent (M.E) of agreement by the respondents that Seafarers manning cabotage vessels are well trained and skilled. The calculated mean of 4.11 shows that the respondents were in support of establishing standard minimum wage for indigenous seafarers. This support the opinion of some respondents interviewed that a standard minimum wage for seafarers will help to prevent exploitation of seafarers by indigenous shipping company.

\section{Conclusion}

The respondents acknowledged that implementation of cabotage act has really been beneficial as it has led to the growth of indigenous shipping companies and increase in the number of Nigerian seafarers employed. However, it is still posed with some challenges such as inability of indigenous shipping companies to access the cabotage vessel financing fund and other loan facility which will help to improve their operations. Also, it was acknowledged that one of the pillars of cabotage act which states that "vessels must be built in Nigeria" seems to be unrealistic and unachievable as the ship building industry in Nigeria does not have the capacity to satisfy the cabotage trade market. Furthermore, the implementation of cabotage act has been successful in the aspect of increase in manning level by Nigerians but the condition of service and welfare of Nigerians seafarers have deteriorated onboard cabotage vessels. 


\section{Recommendations}

It must be noted that implementation of cabotage act presents great potential for growth and development of indigenous shipping companies and contribute to the development of Nigerian economy. Investment (in terms of human and financial) in Nigerian ship building industry will help to meet the demand for cabotage trade market in terms of vessels capacity. Also, it is imperative for Nigeria Maritime Administration and Safety Agency to ensure that Cabotage Vessel Financing Fund (CVFF) is accessible to shipowners to facilitate improved capacity building and operations of indigenous shipping companies or otherwise foreign vessels with the capacity will continue to dominate cabotage trade market.

This study also recommends that more attention should be given to the welfare of indigenous seafarers on board cabotage vessels and necessary mechanism should be put in place in order to ensure effective enforcement of Maritime Labour convention to ensure better working and living conditions, seafarers are paid as at when due and prevent exploitation of Nigerian seafarers by indigenous shipping companies.

\section{Funding}

The authors received no direct funding for this research.

\section{Citation information}

Onwuegbuchunam, D. E., Aponjolosun, M. O., Oludare, A. A., \& Onyekachi. O. C. (2020). Assessment of Cabotage Act implementation and its effect on Nigerian seafarers. Journal of Sustainable Development of Transport and Logistics, 5(1), 124-132. doi:10.14254/jsdtl.2020.5-1.12

\section{References}

Adenubi, T (2018). Cabotage vessel Financing Fund Hits \#37.9bn-NIMASA. Retrieved 30.12.2018 from http://www.tribuneonlineng.com/160066/.

Ajiye, S. (2013). Nigerian Cabotage: Its policy, prospects and challenges. Journal of Economics and Sustainable Development, 4(14), 11-19.

Alayaki, G. (2019). Cabotage finally unbundled from the shackles of waivers. Retrieved from https://www.nimasa.gov.ng/press-centre/post/cabotage-finally-unbundled-from-the-shacklesof-waivers

Bello-Olowookere, G. B. (2011). The effects of cabotage regime on indigenous shipping in Nigeria. World Maritime University Dissertations. Retrieved from http://commons.wmu.se/all_dissertations/176

Casaca, A. C. P., \& Lyridis, D. V. (2018). Protectionist vs liberalised maritime cabotage policies: a review. Maritime Business Review, 3(3), 210-242.

Coastal and Inland Shipping. (2003). Cabotage Act 2003.

Foraminifara Market Research. (2016). Cabotage law and its benefits. Retrieved 05.06.2019 from https://foramfara.com/2016/03/02/cabotage-law-and-its-benefits-to-the-economy-in-Nigeria.

Henry, C.B. (1968). Black's Law Dictionary (4th ed). West Publishing Company.

Igbokwe, M. (2003). The new cabotage act: its intended effect on the local shipping industry. In a paper presented at the annual maritime seminar of the Nigerian Maritime Law Association held on May (Vol. 13).

Igbokwe, M. (2006, July). An Appraisal of the Cabotage Act: Three Years After. In a paper presented at the maritime seminar for judges organized by the Nigerian Shippers' Council at the Eko Le Meridien Hotel, Victoria Island, Lagos in July.

Merriam-Webster. (2019). Cabotage. Retrieved 22.04.2019 from https://www.merriamwebster.com/dictionary/cabotage.

National Inland Waterways Authority (2019). Waterways. Retrieved 17.03.2019 from https://niwa.gov.ng/waterways/

Nigeria's Maritime Industry Forecast (2019). Emerging opportunities and challenges. Retrieved 9/10/2019 from http://nimasa.gov.ng/pdfs/Nigerian_maritime_industry_forecast.pdf. 
NIMASA. (2019). Cabotage service. Retrieved from http://nimasa.gov.ng/.

Njar, G. N., \& Okon, I. E. The impacts of cabotage law implementation on Nigeria's indigenous shipping industry: A study of the Onne Sea Port, Rivers State, Nigeria. European Journal of Logistics, Purchasing and Supply Chain Management, 6(4), 13-27.

Nwekeaku, C., \& Atteh, J. (2016). Cabotage Act and the Challenges of Nigerian Shipping Lines in SubSahara Africa. Advances in Social Sciences Research Journal, 3(5), 39-53.

Oluremi, S.O. (n.d.). Effect of the Cabotage Act 2003 on Nigerian maritime industry. Retrieved 1.1.2019 from http://www.lasu.edu/publications/law/oluremi-savage_oyekunle_bk_2.pdf.

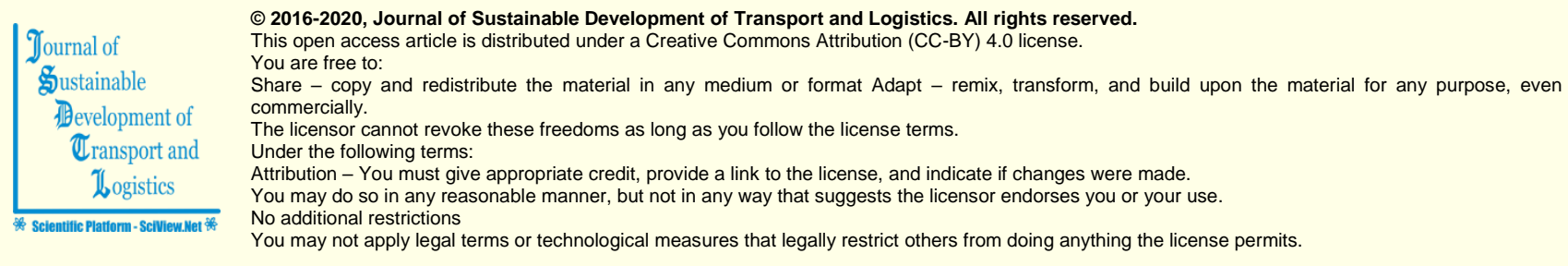

Journal of Sustainable Development of Transport and Logistics (ISSN: 2520-2979) is published by Scientific Publishing House "CSR", Poland, EU and Scientific Publishing House "SciView", Poland, EU

Publishing with JSDTL ensures:

- Immediate, universal access to your article on publication

- High visibility and discoverability via the JSDTL website

- Rapid publication

- Guaranteed legacy preservation of your article

- Discounts and waivers for authors in developing regions

Submit your manuscript to a JSDTL at https://jsdtl.sciview.net/ or submit.jsdtl@sciview.net 